\title{
Kryminologia historyczna jako kierunek badań nad przestępczością kryminalną
}

I. W ostatnich dekadach coraz większe zainteresowanie badaczy budzi zagadnienie przestępczości w perspektywie historycznej. Dotyczy to zarówno przestępczości politycznej, jak i przestępczości kryminalnej ${ }^{1}$, choć - jak się wydaje - w polskiej nauce badania nad przestępczością polityczną dominują nad badaniami dotyczącymi przestępczości kryminalnej.

W wypadku przestępstw politycznych znaczna część dotychczasowych polskich publikacji odnosi się do przestępstw przewidywanych przez ustawodawstwo karne Polski Ludowej, szczególnie w pierwszym dziesięcioleciu jej funkcjonowania.

Obszerna literatura poświęcona jest zagadnieniom związanym z działalnością orzeczniczą i organizacją sądownictwa wojskowego, przede wszystkim wojskowych sądów rejonowych funkcjonujących w pierwszej dekadzie Polski Ludowej. Wśród tego rodzaju prac należy wymienić monografię Jerzego Poksińskiego „, My sędziowie nie od Boga...”. Z dziejów sądownictwa wojskowego PRL 1944-1956. Materiały i dokumenty ${ }^{2}$. Opublikowano także wiele prac dotyczących działalności poszczególnych wojskowych sądów rejonowych. Zagadnienia związane z orzecznictwem oraz obsadą personalną WSR w Krakowie poruszył Filip Musiał w monografii Polityka czy sprawiedliwość. Wojskowy Sad Rejonowy w Krakowie (1946-

${ }^{1}$ Zastrzeżenia do używania terminu „przestępczość kryminalna” wyraził Jerzy Kwaśniewski w artykule Naukowe partactwo, „Profilaktyka Społeczna i Resocjalizacja” 2014, nr 23, s. 151-154. Niemniej wydaje się, że w historycznych badaniach nad przestępczością termin „przestępczość kryminalna" pozwala na odróżnienie jej od przestępczości politycznej.

2 J. Poksiński, ,, My sędziowie nie od Boga...”. Z dziejów sądownictwa wojskowego PRL 19441956. Materiały i dokumenty, Warszawa 1996. 
1955)33. Bohdan Łukaszewicz podjął temat działalności WSR w Olsztynie w publikacji Wojskowy Sad Rejonowy w Olsztynie. Szkice do monografi ${ }^{4}$. Wnikliwej analizie poddał orzecznictwo WSR w Poznaniu Rafał Leśkiewicz w pracy Wojskowy Sąd Rejonowy w Poznaniu (1946-1955)5. Organizację, personalia oraz orzecznictwo WSR w Gdańsku przedstawił Dariusz Burczyk w monografii Wojskowy Sąd Rejonowy w Gdańsku (1946-1955) . Analizę orzecznictwa Wojskowego Sądu Rejonowego w Rzeszowie przedstawiła Ewa Leniart w książce Skazani za antykomunizm. Orzecznictwo Wojskowego Sadu Rejonowego w Rzeszowie (1946-1954/ $1955)^{7}$.

Zainteresowaniem polskich badaczy cieszy się również zagadnienie orzecznictwa sądów powszechnych w sprawach o przestępstwa polityczne. W tym kontekście warto wspomnieć pracę Zdzisława Biegańskiego Sadownictwo i skazani na śmierć z przyczyn politycznych $w$ województwie pomorskim (bydgoskim) w latach 1945-1956 ${ }^{8}$. Krzysztof Sidorkiewicz w pracy Represje wymiaru sprawiedliwości $w$ sprawach politycznych $w$ województwie pomorskim (bydgoskim) w latach 1945-19569 poświęcił jeden z rozdziałów działalności orzeczniczej kujawskich sądów okręgowych. Przestępstwom politycznym należącym do właściwości sądów okręgowych poświęcona została monografia Karola Siemaszki $W$ trudnym okresie odbudowy państwa. Tak zwany maty kodeks kary w świetle orzecznictwa Sadu Okręgowego w Krakowie w latach 1946-195010.

Do prac drobniejszych należy zaliczyć m.in. artykuł Mateusza Woźniaka Przestępstwo „szeptanej propagandy” w świetle wybranego orzecznictwa Sadu Okręgowego w Krakowie z lat 1946-1950 ${ }^{11}$ czy artykuł Karola Siemaszki Criminal

${ }^{3}$ F. Musiał, Polityka czy sprawiedliwość. Wojskowy Sąd Rejonowy w Krakowie (1946-1955), Kraków 2005.

${ }^{4}$ B. Łukaszewicz, Wojskowy Sad Rejonowy w Olsztynie 1946-1955. Szkice do monografii, Olsztyn 2000. 2009.

5 R. Leśkiewicz, Wojskowy Sąd Rejonowy w Poznaniu (1946-1955), Warszawa - Poznań

${ }^{6}$ D. Burczyk, Wojskowy Sąd Rejonowy w Gdańsku (1946-1955), Gdańsk 2012.

7 E. Leniart, Skazani za antykomunizm. Orzecznictwo Wojskowego Sadu Rejonowego w Rzeszowie (1946-1954/1955), Rzeszów 2016.

${ }^{8}$ Z. Biegański, Sąownictwo i skazani na śmierć z przyczyn politycznych $w$ województwie pomorskim (bydgoskim) w latach 1945-1956, Bydgoszcz 2003.

${ }^{9} \mathrm{~K}$. Sidorkiewicz, Represje wymiaru sprawiedliwości w sprawach politycznych $w$ województwie pomorskim (bydgoskim) w latach 1945-1956, Torun 2005.

${ }^{10} \mathrm{~K}$. Siemaszko, W trudnym okresie odbudowy państwa. Tak zwany maty kodeks kary w świetle orzecznictwa Sąu Okręowego w Krakowie w latach 1946-1950, Warszawa 2015.

${ }^{11}$ M. Woźniak, Przestępstwo ,, szeptanej propagandy” w świetle wybranego orzecznictwa Sąu Okręgowego w Krakowie z lat 1946-1950, „Krakowskie Studia z Historii Państwa i Prawa” 2018, t. $11, \mathrm{nr} 4$. 
Liability for Statements in the Light of the Case Law Generated by Regional Courts in Regions Incorporated into Poland Following World War II ${ }^{12}$.

Bogatą bibliografię prac poświęconych pierwszej dekadzie po zakończeniu II wojny światowej zebrał i usystematyzował Andrzej Rzepliński ${ }^{13}$. Zawiera ona ponad 1300 pozycji z lat 1989-1996 - są to prace o charakterze naukowym i publicystycznym, dotyczące przede wszystkim działalności ówczesnych sądów, prokuratury, organów bezpieczeństwa oraz więziennictwa.

W wypadku przestępczości kryminalnej opublikowano wiele znaczących prac odnoszących się głównie do wcześniejszych niż XX w. okresów historycznych. Warto wspomnieć m.in. pracę Marcina Kamlera Złoczyńcy. Przestępczość w Koronie $w$ drugiej połowie XVI i pierwszej połowie XVII wiek ${ }^{14}$. W monografii tej autor przedstawia obraz przestępczości kryminalnej z przełomu XVI i XVII w. w polskich miastach, głównie leżących na ziemiach zachodnich, centralnych i południowych dawnej Korony. Zagadnienia związane z szeroko pojętą historią przestępczości i wymiaru sprawiedliwości w okresie nowożytnym były również przedmiotem pracy Mariana Mikołajczyka pt. Proces kryminalny w miastach Małopolski XVI-XVII wieku ${ }^{15}$. Autor szeroko analizuje postępowanie sądowe w sprawach karnych w prawie miejskim doby nowożytnej, szczegółowo omawiając takie zagadnienia, jak: właściwość sądu, sposób przeprowadzania dowodów czy postępowanie wykonawcze.

Na uwagę zasługuje również praca zbiorowa Przestępczość kryminalna w Europie Środkowej $i$ Wschodniej w XVI-XVIII w. pod redakcją Pawła Klinta i Daniela Wojtuckiego ${ }^{16}$. W przywołanym zbiorze studiów opublikowano m.in. prace D. Wojtuckiego Przestępczość kryminalna we Wrocławiu na podstawie liber proscriptorum z lat 1609-1634 i Małgorzaty Ewy Kowalczyk , Kradnie się i morduje w biały dzień... powszechnie”. Przestępczość we Włoszech w relacjach polskich podróżników doby oświecenia. W tomie zamieszczono również artykuł Jerzego Maronia pt. Wojsko jako grupa przestępcza w XVIII w., poświęcony zagadnieniu przestępstw popełnianych przez żołnierzy. Kwestię przestępstw popełnianych przez żołnierzy stacjonujących w garnizonie krakowskim na przełomie XVIII i XIX w.

${ }^{12}$ K. Siemaszko, Criminal Liability for Statements in the Light of the Case Law Generated by Regional Courts in Regions Incorporated into Poland Following World War II, „Crime, Law and History" 2016, t. 6, z. 2, s. 1-14.

13 A. Rzepliński, Państwo bezprawia - Polska Ludowa 1944-1956. Bibliografia prac naukowych i publicystycznych za lata 1989-1996, „Studia Iuridica” 1998, t. 35.

${ }^{14}$ M. Kamler, Złoczyńcy. Przestepczość w Koronie w drugiej połowie XVI i pierwszej połowie XVII wieku, Warszawa 2010.

${ }^{15}$ M. Mikołajczyk, Proces kryminalny w miastach Małopolski XVI-XVII wieku, Katowice 2013.

${ }^{16}$ P. Klint, D. Wojtucki (red.), Przestępczość kryminalna w Europie Środkowej i Wschodniej w XVI-XVIII w. Warszawa 2017, s. 228. 
poruszył natomiast Michał Baczkowski w artykule Przestępczość wojsk garnizonu krakowskiego na przetomie XVIII i XIX wieku ${ }^{17}$.

W ten nurt badań wpisuje się także edycja źródeł, jak choćby Księga kryminalna miasta Krakowa z lat 1554-1625 ${ }^{18}$ opracowana przez Wacława Uruszczaka, Annę Karabowicz i Macieja Mikułę oraz Księga kryminalna miasta Dobczyc 1699-1737 opracowana przez M. Mikułę ${ }^{19}$.

W ostatnich latach opublikowano również prace poświęcone przestępczości kryminalnej w XX w. Zagadnienie dotyczące przestępczości seksualnej w II Rzeczypospolitej podjął Mateusz Rodak w artykule Przestępstwo zgwatcenia i jego sprawcy w II Rzeczypospolitej. Próba wstępnej charakterystyki $i^{20}$. Kwestię przestępczości seksualnej w latach 40. i 50. XX w., a także problemów wynikających z podejmowania tego rodzaju badań podjął Bartłomiej Międzybrodzki w artykule Problematyka przestępczości seksualnej w latach 40. i 50. XX wieku. Trudności badawcze $^{21}$. W omawiany nurt wpisują się również prace poświęcone wykroczeniom - choć w polskiej tradycji w zasadzie nigdy nie zaliczano ich do kategorii przestępstw, to są one czynami szkodliwymi społecznie. $Z$ tego względu należy wspomnieć o pracach poruszających tę tematykę. O wykroczeniach w Polskiej Rzeczpospolitej Ludowej pisał przede wszystkim Marcin Łysko, m.in. w pracach: Ksztaltowanie polityki karnej w sprawach o wykroczenia przez aparat administracji Polski Ludowej22 oraz System sankcji w prawie wykroczeń europejskich państw socjalistycznych ${ }^{23}$.

II. Badania nad historyczną przestępczością cieszą się również znaczną popularnością w innych krajach Europy. W literaturze europejskiej już na przełomie

${ }_{17}$ M. Baczkowski, Przestępczość wojsk garnizonu krakowskiego na przełomie XVIII i XIX wie$k u$, „Krakowskie Studia z Historii Państwa i Prawa” 2012, t. 5, z. 2.

${ }^{18}$ Księga kryminalna miasta Krakowa z lat 1554-1625, oprac. W. Uruszczak, A. Karabowicz, M. Mikuła, Kraków 2013.

${ }_{19}$ Księga kryminalna miasta Dobczyc. 1699-1737, oprac. M. Mikuła, Kraków 2013.

${ }^{20}$ M. Rodak, Przestęstwo zgwatcenia i jego sprawcy w II Rzeczypospolitej. Próba wstepnej charakterystyki, „Studia z Dziejów Państwa i Prawa Polskiego” 2013, t. XVIII.

${ }^{21}$ M. Międzybrodzki, Problematyka przestępczości seksualnej w latach 40. i 50. XX wieku. Trudności badawcze, „Sensus Historiae” 2013, t. X, nr 1.

${ }_{22}$ M. Łysko, Ksztaltowanie polityki karnej w sprawach o wykroczenia przez aparat administracji Polski Ludowej [w:] T. Bykowa, A. Górak, J. Legieć (red.), Dzieje biurokracji, t. 8, Lublin 2018.

${ }^{23}$ M. Łysko, System sankcji w prawie wykroczeń europejskich państw socjalistycznych, „Miscellanea Historico-Iuridica" 2017, t. 16, z. 1, s. 191-207. Autor ten kwestii wykroczeń poświęcił również monografię pt. Prace nad kodyfikacją materialnego prawa wykroczeń w Polsce Ludowej (1960-1971), Białystok 2016, jednak opracowania dotyczące kodyfikacji trudno zaliczyć do badań nad przestępczością. 
lat 70. i 80. XX w. wskazywano, że ta tematyka badawcza zawdzięcza swoją pozycję i popularność badaniom podejmowanym we francuskiej szkole historycznej związanej z czasopismem „Annales. Histoire, Sciences Sociales”24, choć zwracano również uwagę na istotną rolę badań brytyjskich i amerykańskich ${ }^{25}$.

Wspomniane czasopismo odegrało ważną rolę w promowaniu badań nad historią przestępczości w drugiej połowie XX w. Wśród publikowanych na jego łamach artykułów poświęconych tej problematyce można wskazać pracę François Billacois, Pour une enquête sur la criminalité dans la France d'Ancien Régime ${ }^{26}$, a także pracę André Abbiateciego Les incendiaires dans la France du XVIIIe siècle: Essai de typologie criminelle ${ }^{27}$, bazującą na zachowanych aktach spraw karnych o podpalenia rozpoznanych przez paryski Parlament. Ponadto zaznaczenia wymaga, że w 2007 r. jeden z numerów „Annales. Histoire, Sciences Sociales” niemal w całości poświęcono zagadnieniom przestępczości historycznejej ${ }^{28}$. Badania nad przestępczością historyczną podejmowano też w innych państwach francuskiego obszaru językowego. Przykładowo można wymienić pracę Raymonda Boyera Les crimes et les châtiments au Canada français du XVIIe au XXe siècle $e^{29}$. Była to jedna z pierwszych prac poświęconych historii przestępczości w Kanadzie, w której autor przedstawił nie tylko przestępczość w okresie kolonialnym, ale także historię więziennictwa.

Tematyką kryminologii historycznej czy badań nad przestępczością historyczną od dawna zajmuje się także nauka niemiecka. W 1951 r. została wydana książka Gustava Radbrucha i Heinricha Gwinnera Geschichte des Verbrechens. Versuch einer historischen Kriminologie ${ }^{30}$. Autorzy tej monografii analizowali zachowania przestępne w różnych okresach historycznych, od starożytności do początku XIX w. Warto wspomnieć również pracę Dirka Blasiusa, Moniki Pelz i Sebastiana Scheerera, Historische Kriminologie $e^{31}$, wydaną w serii „Kriminalsoziologische

${ }^{24}$ Por. D. Blasius, Kriminologie und Geschichtswissenschaft. Bilanz und Perspektiven interdisziplinärer Forschung, „Geschichte und Gesellschaft” 1988, t. 14, nr 1, s. 144.

${ }_{25}$ D. Blasius, Kriminalität und Geschichtswissenschaft perspektiven der neueren forschung, „Historische Zeitschrift” 1981, t. 233, s. 615.

${ }^{26}$ F. Billacois, Pour une enquête sur la criminalité dans la France d'Ancien Régime, „Annales. Histoire, Sciences Sociales" 1967, t. 22, nr 2, s. 240-249.

27 A. Abbiateci, Les incendiaires dans la France du XVIIIe siècle: Essai de typologie criminelle, „Annales. Histoire, Sciences Sociales” 1970, t. 25, nr 1, s. 229-248.

${ }^{28}$ „Annales. Histoire, Sciences Sociales” 2007, t. 62, nr 5.

${ }^{29}$ R. Boyer, Les crimes et les châtiments au Canada français du XVIIe au XXe siècle, Montreal 1966.

${ }^{30}$ G. Radbruch, H. Gwinner, Geschichte des Verbrechens. Versuch einer historischen Kriminologie, Stuttgart 1951.

${ }^{31}$ D. Blasius, M. Pelz, S. Scheerer, Historische Kriminologie, „Kriminalsoziologische Bibliografie", t. 25, Wien 1979. 
Bibliografie". W tomie tym opublikowano artykuł D. Blasiusa Kriminalität als Gegenstand historischer Forschung ${ }^{32}$.

Badania nad przestępczością historyczną prowadzono również w nauce brytyjskiej ${ }^{33}$. Wiele tekstów poświęconych tej tematyce publikowanych jest w brytyjskim periodyku „Law, Crime and History”34. Prace dotyczące szeroko pojętej historii przestępczości publikowane są także na łamach wydawanego we współpracy z British Society of Criminology czasopisma „Criminology and Criminal Justice" ${ }^{35}$. Zagadnieniom płci i przestępczości poświęcono jeden $\mathrm{z}$ numerów periodyku „Journal of Social History” ${ }^{36}$. Warto też zwrócić uwagę, że w ramach British Society of Criminology funkcjonuje sekcja kryminologii historycznej ${ }^{37}$.

Wspomniana tematyka badawcza jest podejmowana również w nauce holenderskiej. W tym kontekście należy przywołać książkę Marion Pluskoty Prostitution and Social Control in Eighteenth-Century Port ${ }^{38}$, w której autorka, korzystając z dostępnych danych sądowych i policyjnych, analizuje proces zmiany sposobu postrzegania prostytutek w XVIII w. Kwestię przestępczości kobiet na przestrzeni XVII-XVIII w. poruszyła również Manon van der Heijden w pracy Women and Crime in Early Modern Holland ${ }^{39}$.

Prace z zakresu historii przestępczości regularnie publikuje czasopismo „Crime, History and Societes" wydawane pod auspicjami International Association for the History of Crime and Criminal Justice.

Badania z zakresu kryminologii historycznej prowadzono również w Skandynawii. Już w pierwszym numerze założonego w 1976 r. czasopisma „Scandinavian Journal of History" opublikowano dwie prace z tego obszaru badań. Heikki Ylikangas $\mathrm{w}$ artykule Major fluctuations in crimes of violence in Finland ${ }^{40}$ podsumowat

${ }^{32}$ D. Blasius, Kriminalität als Gegenstand historischer Forschung [w:] D. Blasius, M. Pelz, S. Scheerer, Historische Kriminologie, s. 1-15.

${ }^{33}$ Por. H. Johnston, Crime in England 1815-1880: Experiencing the criminal justice system, London 2015; C. Emsley, Crime and Society in England 1750-1900, London 1987; F. McLynn, Crime and Punishment in Eighteenth-century England, London 1989.

${ }^{34}$ Por. C. Sandford-Couch, H. Rutherford, From the 'Death of a Female Unknown' to the Life of Margaret Dockerty: Rediscovering a Nineteenth Century Victim of Crime, „Law, Crime and History" 2018, t. 8, z. 1, s. 21-37.

${ }_{35}$ Por. H. Johnston, Imprisoned mothers in Victorian England, 1853-1900: Motherhood, identity and the convict prison, „Criminology and Criminal Justice” 2019, t. 19, z. 2.

36 W „Journal of Social History” 2018, t. 51, z. 4 - w sekcji „Crime and gender” - opublikowano m.in. artykuły: M. van der Heijden, S. Muurling, Violence and Gender in Eighteenth-Century Bologna and Rotterdam; B. Althammer, Roaming Men, Sedentary Women? The Gendering of Vagrancy Offenses in Nineteenth-Century Europe.

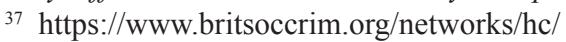

${ }^{38}$ M. Pluskota, Prostitution and Social Control in Eighteenth-Century Port, New York 2015.

${ }_{39}$ M. van der Heijden, Women and Crime in Early Modern Holland, Leiden 2016.

${ }^{40} \mathrm{H}$. Ylikangas, Major fluctuations in crimes of violence in Finland, ,Scandinavian Journal of History" 1976, t. 1, nr 1, s. 81-103. 
swoje dotychczasowe badania nad fińską przestępczością, które prowadził od kilku lat, natomiast Jan Sundin w artykule Theft and Penury in Sweden 1830-1920 ${ }^{41}$ poruszył kwestię przestępstw kradzieży w XIX-wiecznym społeczeństwie szwedzkim. Obie przywołane prace, a także sam fakt powstania czasopisma „Scandinavian Journal of History" zostały zauważone również w Polsce. Andrzej Wyrobisz w artykule Nowy periodyk skandynawski ,Scandinavian Journal of History” opublikowanym na łamach „Zapisków Historycznych. Kwartalnika poświęconego historii Pomorza" nie tylko streścił oba przywołane teksty, ale także wskazał na znaczącą popularność kryminologii historycznej i jej perspektywy jako nowego narzędzia służącego poznaniu społeczeństwa i przemian w nim zachodzących ${ }^{42}$. Publikacje poświęcone przestępczości pojawiały się na łamach wspomnianego periodyku także w późniejszych numerach - warto wspomnieć choćby artykuł Jeppego Bücherta Netterstrøma Criminalization of Homicide in Early Modern Denmark (16th-17th

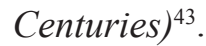

III. Mimo podobnego obszaru badań kryminologia historyczna nie może być utożsamiana $\mathrm{z}$ badaniami nad historią przestępczości. Kwestie związane z wzajemną relacją kryminologii i badań historycznych nad przestępczością poruszyli brytyjscy badacze Barry S. Godfrey, Chris A. Williams i Paul Lawrence w książce History and Crime $e^{44}$. Określili oni relacje kryminologii i historii przestępczości jako sytuację, w której w niewielkim pomieszczeniu znajdują się dwa wzajemnie ignorujące się słonie ${ }^{45}$. Niemniej w polskiej literaturze termin ten bywa używany na określenie badań nad szeroko ujętą historią przestępczości ${ }^{46}$. W zasadzie w nauce polskiej utożsamia się kryminologię historyczną z historycznymi badaniami przestępczości, traktując ją jako nurt w historiografii ${ }^{47}$.

Problem właściwego zdefiniowania kryminologii historycznej jest także podejmowany w nauce europejskiej ${ }^{48}$. Dostrzega się, że sam termin „kryminologia historyczna" wskazuje poniekąd na zaangażowanie dwóch dziedzin nauki, mianowicie kryminologii i historii ${ }^{49}$. Jest to zatem nurt o charakterze interdyscyplinarnym,

41 J. Sundin, Theft and Penury in Sweden 1830-1920, „Scandinavian Journal of History” 1976, t. 1, nr 1, s. 265-292.

${ }^{42}$ A. Wyrobisz, Nowy periodyk skandynawski „Scandinavian Journal of History”, „Zapiski Historyczne. Kwartalnik poświęcony historii Pomorza” 1978, t. 43, z. 3, s. 118.

${ }_{43}$ J.B. Netterstrøm, Criminalization of Homicide in Early Modern Denmark (16th-17th Centuries), „Scandinavian Journal of History” 2017, t. 42, nr 4, s. 459-475.

${ }^{44}$ B.S. Godfrey, C.A Williams, P. Lawrence, History and Crime, London 2008.

${ }^{45}$ Ibidem, s. 2.

${ }^{46}$ P. Klint, D. Wojtucki (red.), Przestępczość kryminalna..., s. 7.

${ }^{47}$ Ibidem.

48 D. Churchill, Towards Historical Criminology, „Crime, History and Societies” 2017, t. 21, nr 2, s. 379-386.

${ }^{49}$ Ibidem. 
przy czym wiodącą rolę należy przypisać kryminologii. W nauce niemieckiej już w latach 80. XX w. sformułowano główne cele badawcze kryminologii historycznej, kładąc nacisk na to, iż nie może się ona ograniczać do badań nad przestępczością historyczną i powinna szukać odniesienia do współczesnych zagadnieńn ${ }^{50}$.

$\mathrm{O}$ ile bowiem głównym celem historycznych badań nad przestępczością jest wyjaśnienie tego zjawiska w przeszłości, o tyle celem kryminologii historycznej jest przełożenie wyników badań nad przestępczością historyczną na współczesne praktyki w dziedzinie wymiaru sprawiedliwości czy wykazanie kontynuacji lub zmian w zachowaniach przestępnych na danym obszarze w określonym czasie, a także wyjaśnienie współczesnych zjawisk o charakterze przestępnym poprzez odniesienie ich do historycznych form przestępczości ${ }^{51}$. Cel ten kryminologia historyczna stara się osiągnąć za pomocą przeniesienia pojęć i metod badawczych z historii na obszar studiów nad przestępczością i wymiarem sprawiedliwości ${ }^{52}$. Trzeba też zaznaczyć, że badania historyczno-kryminologiczne muszą opierać się na pewnej podstawie źródłowej, czyli materiale źródłowym wytworzonym przez organy wymiaru sprawiedliwości i instytucje powołane do ścigania przestępstw, choć nie należy też zapominać o źródłach wytworzonych przez jednostki szeroko pojętej administracji ${ }^{3}$.

W konsekwencji celem kryminologii historycznej jest nie tyle „odkrywanie” zjawisk związanych z historyczną przestępczością, ile wyjaśnianie współczesnej przestępczości przez pryzmat historycznej analizy zjawisk przestępnych. Tak ujęty cel kryminologii historycznej traktuje ten nurt jako interdyscyplinarny z samego założenia kryminologii, która jest nauką zajmującą się nie tylko przestępstwem i przestępcami, ale także przyczynami przestępczości ${ }^{54}$. Należy zatem postrzegać kryminologię historyczną nie jako nurt w naukach historycznych, ale raczej nurt w kryminologii, który czerpie z dorobku obu tych nauk ${ }^{55}$.

W literaturze podkreśla się, że tak sformułowany cel kryminologii historycznej może być realizowany według trzech podejść badawczych.

Pierwszym z nich jest analiza porównawcza, a więc wykorzystanie zebranych w trakcie badań historycznych danych jako swoistego punktu odniesienia do współczesnej przestępczości bądź zjawisk bezpośrednio z nią związanych ${ }^{56}$. Drugim

${ }^{50}$ D. Blasius, Kriminologie und Geschichtswissenschaft..., s. 136-149.

${ }^{51}$ P. Lawrence, Historical criminology and the explanatory power of the past, „Criminology \& Criminal Justice" 2019, t. 19, nr 4, s. 2.

${ }^{52}$ P. Knepper, Historical Criminology [w:] G. Bruinsma, D. Weisburd (red.), Encyclopedia of Criminology and Criminal Justice, New York 2014, DOI: https://doi.org/10.1007/978-1-4614-56902_100299 [dostęp: 19.08.2019].

${ }_{53}$ Por. D. Blasius, Kriminologie und Geschichtswissenschaft.., s. 147.

${ }_{54}$ B. Hołyst, Kryminologia, wyd. 11, Warszawa 2016, s. 51.

${ }_{55}$ D. Churchill, Towards Historical...

${ }^{56}$ P. Lawrence, Historical criminology..., s. 3. 
podejściem jest wykazanie kontynuacji pewnych zjawisk i form przestępczości istniejących w przeszłości i poprzez takie zestawienie zarysowanie sposobu rozwiązania danego problemu istniejącego współcześnie ${ }^{57}$. Do obszaru zainteresowania kryminologii historycznej zalicza się także badania nad tradycjami instytucjonalnymi czy pewnymi przekonaniami (przesądami) funkcjonującymi wśród ludności i ich wpływem na kształt współczesnej przestępczości ${ }^{58}$. Trzecim podejściem badawczym $w$ ramach kryminologii historycznej jest podjęcie długoterminowej analizy zjawiska przestępczości i ukazania w ten sposób ciągłości pewnych procesów, jak również dokonanie analizy współczesnej przestępczości na podstawie badań obejmujących znaczny okres ${ }^{59}$. Badania takie mogą dotyczyć np. przestępczości przeciwko życiu i zdrowiu czy polityki kryminalnej prowadzonej przez państwo na przestrzeni stu lat i na końcu odnosić się do przyjętych współcześnie rozwiązań ${ }^{60}$.

W literaturze zauważa się, że wszystkie te trzy podejścia mają prowadzić do zrozumienia współczesnej przestępczości i wskazania, które z zachodzących współcześnie procesów są nowe, a więc wymagają większej uwagi wymiaru sprawiedliwości, a które z nich są właściwe przeszłości, a więc co do zasady były już obiektem zainteresowania wymiaru sprawiedliwości i nie wymagają takiego zaangażowania sił i środków jak nowe zjawiska patologiczne ${ }^{61}$.

Jednocześnie w literaturze nie brakuje głosów krytycznych wobec omawianego nurtu badawczego. Przede wszystkim podkreśla się, że kryminologia historyczna nie wypracowała dotychczas jednolitej siatki pojęciowej ani metodologii badań i wspólnych dla całego kierunku narzędzi badawczych ${ }^{62}$. Trudno zatem mówić o kryminologii historycznej jako o określonym kierunku badawczym w kryminologii na wzór np. kierunków socjologicznych czy biologicznych. Nadal postrzega się kryminologię historyczną przez pryzmat badań prowadzonych przez poszczególnych badaczy, a nie jako spójny kierunek badawczy cechujący się szerzej uzna-

57 Ibidem, s. 3.

${ }^{58}$ D. Churchill, Towards Historical...

59 P. Lawrence, Historical criminology..., s. 4.

${ }^{60}$ Jako modelowy przykład tego rodzaju badań podaje się publikację B.S. Godfrey, D.J. Cox, S.J. Farrall, Serious Offenders: A Historical Study of Habitual Criminals, Oxford 2010, w której autorzy odnoszą się nie tylko do norm prawnych dotyczących „poważnych przestępców”, obowiązujących w latach 1840-1940, i analizują dane związane z 297 sprawcami, ale także odnoszą się do współczesnej polityki kryminalnej w Wielkiej Brytanii. Por. recenzję tej monografii: C. Emsley, Godfrey (Barry S.), Cox (David J.), Farrall (Stephen J.), Serious Offenders: A Historical Study of Habitual Criminals, „Crime, History \& Societies” 2012, t. 16, nr 1, http://journals.openedition. org/chs/1333 [dostęp: 20.08.2019].

${ }^{61}$ Ibidem. Por. B.S. Godfrey, C.A Williams, P. Lawrence, History and Crime, gdzie autorzy w tytule rozdziału II używają terminu historical criminology również w cudzysłowie.

${ }^{62}$ D. Churchill, Towards Historical... 
nymi w świecie naukowym paradygmatami. Powyższe spostrzeżenia prowadzą w konsekwencji, zdaniem niektórych badaczy, do konieczności stosowania terminu „kryminologia historyczna” tylko i wyłącznie w cudzysłowie ${ }^{63}$.

W Polsce można wskazać przynajmniej kilka obszarów, w których prowadzenie badań z zakresu „kryminologii historycznej” mogłoby przynieść interesujące wyniki. Jednym z nich jest zagadnienie przestępczości kryminalnej na ziemiach zachodnich przyłączonych do Polski po zakończeniu II wojny światowej, tym bardziej że w archiwach państwowych zachowały się materiały, przede wszystkim akta sprawa karnych ${ }^{64}$, które pozwoliłyby na dokonanie interesujących ustaleń badawczych.

IV. Termin „kryminologia historyczna” funkcjonuje w nauce europejskiej co najmniej od drugiej połowy XX w. Mimo to wydaje się, że kryminologia historyczna jest koncepcją wymagającą jeszcze doprecyzowania i wypracowania własnych, jednolitych metod badawczych i spójnych założeń. Nie można też wykluczyć, że nigdy nie dojdzie do powstania pełnoprawnego kierunku historycznego w kryminologii, a sama kryminologia historyczna będzie jedynie efemeryczną koncepcją bądź luźnym zbiorem badań nad powiązaniem przestępczości historycznej i współczesnej, bez wspólnego mianownika metodologicznego i pojęciowego. Nie budzi wątpliwości, że obecnie nie należy utożsamiać kryminologii historycznej z badaniami nad przestępczością historyczną z uwagi na odmienne założenia i cele badawcze tych dyscyplin, choć kategoryczne ich rozgraniczenie może być trudne. W literaturze zauważa się, że już obecnie znaczną część badań nad historią przestępczości trudno zaszeregować jednoznacznie do obszaru badawczego kryminologii bądź historii z uwagi na daleko idące zbieżności, a proces ten w ocenie niektórych badaczy będzie się pogłębiał ${ }^{65}$. Niemniej podkreślenia wymaga to, że kryminologia historyczna sięga w swych badaniach do metod właściwych dla kryminologii, jak np. analiza danych ilościowych.

Mimo powyższych zastrzeżeń ta interesująca koncepcja, wymagająca w gruncie rzeczy badań o charakterze interdyscyplinarnym, może doprowadzić do ciekawych rezultatów badawczych na styku historii, historii prawa i kryminologii.

${ }^{63}$ Ibidem.

${ }^{64} \mathrm{Na}$ przykład w Archiwum Państwowym w Zielonej Górze w zespole Sądu Okręgowego w Zielonej Górze zachowały się akta 97 spraw o przestępstwa kryminalne rozpoznawanych w latach 1945-1950. Por. inwentarz zespołu nr 89/433 Sądu Okręgowego w Zielonej Górze. W wypadku zespołu Sądu Okręgowego w Głogowie, znajdującego się w tym samym archiwum, zachowały się akta 48 spraw karnych z lat 1945-1950.

${ }^{65}$ B.S. Godfrey, C.A Williams, P. Lawrence, History and Crime, s. 21-22. 


\title{
HISTORICAL CRIMINOLOGY AS A DIRECTION OF RESEARCH INTO CRIME
}

\begin{abstract}
The term "historical criminology" has been present in science for about twenty years. The main assumption of this relatively new research trend is the analysis of contemporary crime through the prism of historical research. Therefore, research into the history of crime and historical criminology, which are also popular in Poland, cannot be equated. The article presents the assumptions of this trend in criminology. At the same time, it indicates the doubts which appear in the literature on the subject matter concerning the distinguishing of historical criminology as a fully-fledged trend in criminology.
\end{abstract}

Keyw ords: history of crime, historical criminology, crime 